\title{
Cognitive Trap: Misperceptions in the US and China Relations
}

\author{
Weimin Wang $^{1}$, \& Shitao Huo ${ }^{2}$ \\ ${ }^{1}$ Dean of School of Government at Shanghai University of Political Science and Law, China \\ ${ }^{2}$ Shanghai University of Political Science and Law, China \\ Correspondence: Shitao Huo, Shanghai University of Political Science and Law, China.
}

Received: March 30, 2020

doi:10.11114/ijsss.v8i4.4886
Accepted: May 28, 2020

Available online: June 3, 2020

URL: https://doi.org/10.11114/ijsss.v8i4.4886

\begin{abstract}
Existing scholarship focuses on power or dysfunctional institutions to explain instability of international relations and resulting conflict among great powers. We argue that the extant deterioration of the US-China relation is the result of cognition based on self-centric generated misperception. Our study shows that rather than asymmetric power distribution or the dysfunctional institutions, it is biased and distorted cognition that trigger misunderstanding, which ultimately invites the spiral escalation of suspicions and hostile competition between the two sides. Our argument is primarily justified by our critique over normative approaches, and our proposed political-cognitive model; and then we evaluate the political implications of neglected commonalities, ignored distinctions and exaggerated differences in each party's cognitive processes. Utilizing several analytical variables incorporating observable past experiences and current development in the power transition and in domestic politics of both countries, we found how often the states can be easily galvanized into actions of hostility with misperceptions; and how easy a benign environment for co-evolution can be cooked down to vicious situation for confrontation. We concluded that any action taken by great powers in their relations are the result of cognitive approaches. Clarifying ignorance and misinterpretations in their cognitive activities help mitigate the tensions instigated by biases and distortions. Competition through reciprocity for the great power relations is critical not only due to the deadly constraints in the militarily option, it is pragmatically most cost-beneficial because all it requires is to nurture appropriate cognition that respects the difference over uniformity, and trust regime's rationality for innovation.
\end{abstract}

Keywords: cognition, perception, the US China relations, foreign policy

\section{Introduction}

\subsection{Introduction to the Problem}

In our ongoing observation and discussion on the subject of the great power relations between the US and China, one of the unexpected discoveries we made as we determined what factors dictated the communication and policy decisions between the two countries was that biased and distorted cognition entice misunderstandings, and thereupon led to the escalation of hostile competition in today's bilateral relations.

\subsection{Cognition in Human Relations - Past and Present}

Neuroscience and life experience have all revealed how human brain works and factors that may help or hurt our ability for a perfect comprehension. Over the last one thousand years, human society has recorded countless instances of healthy cognitive process and resulting achievements in technology and modern civilization; and of the ramifications of cognitive distortion that mostly led to violence and wars. Review of human conflicts pieces together many tragedies due to cognitive biases. Following the logic of biased cognition, reinforced by the extreme nationalist sentiments, all other benign alternatives tended to be opted out during a malign competition. Thus, human has to pay heavy prices for their own misperceptions. Peace, the seemingly lofty objective looks only pretty on paper, and thus a step too far to reach.

\subsection{Research Methodology and Variables}

The research reported in this article is designed to investigate the agents for policy understanding, analysis and decisions in great powers' relations. Its methodology is associated with the role of communications in international relations, but we examined the cognitive activities driven by political psychology. We also established analytical structure to explore the effects of variables such as historical analogy, self-centric perceptions, and the denial of rational 
versus empathetic, altruistic consideration and assuming rationality.

This study argues that the fundamental changes in extrinsic and intrinsic conditions in post Cold War era destine co-evolution relation between the two countries for now and so many years to come. However, ignorance and misperceptions in four faceted areas proved to be critical agents leading to a much troubled relations between the two. First, the neglected similarities shared in both histories, educational systems, and psychological mentalities are the basis for ambivalence each feels about the other. Secondly, the mostly intentionally ignored cognitive differences in state building, and their world views are the deepest sources to the never ending debate between the two sides on political morality and solutions to problems in the international relation. Thirdly, the neglected similarities and exaggerated differences between the two powers are prescribed as ideological yet can be actually compromised through the lens of utilitarianism. Finally, the attitudes of tolerance and rationality are missing in their way of communications. But self-conscious sensitivity for rationality are necessary for them to explore a comfort zone, where both may want to play the game of discourses and moving towards at least an "uncomfortable consensus." That is just because we believe that any actions taken by great powers in their relations are the result of cognition.

\subsection{Rational Cognitive Approach to the Relations}

Our findings were convincing to say the least, the current relations between the US and China are still promising if both sides would come to a clear recognition of their neglected similarities, and of exaggerated differences. Even tentative tolerance to differences and allow self-directed correction over heterodoxy will compromise unnecessary hostility motivated by conventional views of powers and institutions.

\section{Cognitive Trap and International Relations}

\subsection{What is A Cognitive Trap?}

Cognitive trap refers to the tendency of pitting one's own perception against the reality. One simple life example for cognitive trap is defined as cognitive distortion. When something negative happens to ones who are normally happy rational people, they would commonly perceive reality differently, which triggers feelings of negativity, pessimism and even depression. From neuroscience standpoint, when you perceive things negatively, your thoughts were overwhelmed by pervasive negativity. That is simply because during the process of understanding, you misinterpreted the information you are receiving. Therefore, it is your twisted thinking that should be blamed for your unhappiness (Burns, 2008).

It is found that cognitive trap can be of the results of personality and or organizational culture (Heuer, 2007). The personality type of cognition assumes the people or events being studied think and act like person who conducts the analysis. Another word for this phenomenon is called mirror-imaging. This type of thinking and action pattern follows such line of the logic - you are just the opposite of who I am. Organizational culture type of cognition finds that individual actors working in a collective environment would tend to agree with one another and no one challenges acknowledged authority in the group.

Being personal or organizational, both cultures share the traits in the following approaches: inappropriate analogies, ethnocentric assumption, lack of empathy, and denial of rationality - same methodological, psychological and cultural causes for the distorted cognitive thinking (Heuer, 2007). Similar analytical syndrome can be found in international relations and its studies. Conflict and wars occurring repeatedly between nations and among state alliances are the revelations of what and how individuals and groups perceive others during conflict.

\subsection{Cognitive Trap and International Relations}

One commonly well-known cognitive trap in their biased and distorted analysis is prescribed by students of IR as mirror - image syndrome. And thus developed theoretical variations encompass issues of security dilemma, group thinking, game theories and so forth (Jervis 1978; Allison 1999). States in confrontation would normally take ethnocentric postures and accuse their counterparts of being erroneous and wicked. Therefore, a further analysis based on such misperceived inference will be deduced as evidence of threat to the national security. A correlative consequence of misperceptions between antagonistic rivalries would naturally seek armaments for protection. And thus it is turned quickly to a never ending spiral escalation of arms race. In addition, so many historical lessons show that on top of distorted perceptions, extreme nationalist sentiments could add fuel to the flames of on fired animosity.

\subsection{Traits of Cognitive Thinking}

Inappropriate analogies have been widely used during the debate in the IR studies. Among many works on the US China relations in recent years, we have witnessed so much enthusiasm on a discussion about so called "Thucydides Trap". Using historical cases, the author assumes most established states and rising states cannot stay away from hostile conflict. They are destined for war. Why? It is because the history says so. As it argues that this analytical analogy will prove extremely accurate and useful particularly in the case of the US and China relations as a rising China and existing 
hegemon cannot get along due to their fundamentally incompatible core national interests, and to China's intention to displace the US (Allison, 2015 \& 2017). The Allison's preordained path to the Thucydides Trap theory has been criticized for his misperceived relations between the two powers and his ignorance over the cooperative efforts through negotiations on regular basis between the overarching leaders of both countries (Wang W. Z.Y., 2019). Evidently, justifying his argument through enlisting fancy cases of past wars meant to claim the legitimacy in his analogy analysis. By doing so, however, he fails to realize a trap into which he could have fallen when an analyst is obsessed with inappropriate analogies. History never repeats itself as some other students of IR have alerted (Bull, 1977; Jervis, 1988). Any single case of history can be an exception and allowing one dominant perspective to justify an attitude of complacency by rejecting other elements is without foundation.

Flawed cognitive capacity could also generate misperception that may entice misjudgment and most likely irritate public opinion and seduce extreme nationalist sentiments. The 1930's German leaders utilized innocent patriotism and turned them all into an extreme nationalism. This provides undisputable precedence for what a distorted cognition could do to the destiny of human community. With rapidly spreading consensus in the US upon the theories of the end of history (Fukuyama, 1992), and an awakening Islamism and a rising China as the threats to the modernity created by the omnipotent Christianity civilization (Huntington, 1996), some mainstream strategists and scholars in America have been made so convinced that China refuses western value and system, and has kept preserving its obstinate and imprudent authoritarianism and state directed economy. Therefore, just like what the US did to the Soviet Union, another Cold War is needed to force China to do what the US wants (Yan, 2018).

Two historical lessons learned from aforementioned human conflict, hot or cold, exemplifies what that it takes for misperceptions to grow from its embryo. And they are ethnocentric assumption and total lack of empathy. As commonly acknowledged that most of the wars, Peloponnesian War included, could not have happened if a different approach had been taken. What if Austria-Hungarian took the assassination of Archduke France Ferdinand as an isolated incident by a Slavic extremist; or if German utilized all means of diplomacy before it carried out strong commitment to its ethnic allies (Allen, 2014), Europe could have escaped a war that annihilated its thirteen million people. Similarly, by the time WW II ended, the Soviet Union suffered from enormous loss of life - over twenty million people - and a much fragile state capacity. It could easily turn paranoid when facing loads of pressures from an unfriendly west. What if George Kennan didn't misconceive Soviet power (Lippmann, 1973; American Foreign Relations Paper), neither sides would have to wrestle with one another squandering their capitals and endeavors in the next several decades for terminal weapons and end up drastically demolishing them.

Beside the syndromes of mirror image, inappropriate analogy, ethnocentric assumption and total lack of empathy, the thinking approach of cognitive trap denies opponents' rationality - its consciousness and capacity of self-correction. We can call it the denial of rationality - a derivative of biased cognitive thinking. The great debate and battle between Capitalism and Socialism since the 19th century was always carried away by a monolithic perception that assumes evil nature of the opponent and refuses to credit the regime resilience. However, history has demonstrated what rational people could do to redress the insufficiencies of the socioeconomic systems, and rejuvenate the legitimacy of the regime. A quintessential example is found from Marxist sharp criticism on early stage of Capitalism. Together with the observation by his political disciples from Russia, strong socialist movement insurgence spread all over Europe and part of Asia. It was their religious believe that Capitalism is destined to perish which will give way to much ideal typed society in Socialism (Marx, 1996; Lenin, 1996). However, things have gone just different routes in western capitalist countries. A pronounced to be doomed mortal capitalism turns out a solid mass consumption society. Greatest economic miracles have been created one after another on the land of western capitalism, which really has become the source of vibrancy, and the "beacon" of the liberty.

In opposition to the revival of European capitalism, another case in the same vein of logic has obviously locked up with the fact of a sea change in the contemporary socialist China. The earth shaking transformation in China since the 1980's has not only brought to its people enormous amount of wealth, sense of happiness, it is a formidable testimony for what a rational people could do after years of reflective contemplation mingled with hard work. It is really a story about the regime resilience, how an unpopular government turns itself into a highly sufficient and respectful machine of governance. Those who crowns himself a prophet of China with "coming collapse" theory (Chang, 2001) could probably find very few resonance today even among his alike.

\section{The US and China: How Do They Look at Each Other Today?}

\subsection{What Has Happened in China in the Recent Decades?}

In less than 40 years, China has transitioned from a low end agrarian society to a quasi industrialized power. According to the living data by the UN and other international organizations, China's poverty alleviation of eight hundred million population, world's number two economy by GDP, and affluent middle class people at four hundred million, are just a 
few examples among innumerous many. Similarly, China contributes $30 \%$ of world's growth in the last several years (Worstall, 2016); is world's number one contributor to the UN peace keeping mission in personnel and the second largest as financial donor (Sheng, 2016; Wang, M. Z. 2016); and the leader of an UN endorsed project for a would be grand prosperity areas through its Belt and Road Initiative.

\subsection{Chinese Ambivalence about America}

Many in America would wonder what and how Chinese people view American and its role in a changed China. That is because Americans like to believe it is the US that creates opportunities for China to an open world market and the modernity (Zhao, 2014). Chinese people did appreciate the mutual visitations by the supreme leaders of both countries since Richard Nixon; the enlightening speeches given by Nobel laureate on the value of private property and free market; the American generosity in locating exchanged personnel to receive training and education in the US; the pouring businesses like McDonalds, Kentucky Chicken, Starbucks to feed the taste and curiosity of Chinese people; and eventual permission to allow China become a member of WTO. In many ways, Chinese people view American as role model for market development, and are so fascinated by American's charismatic innovation and contributions to the modern technology and urban modernization. However, multiple events occurring during every presidency since the 1990 have greatly compromised what it could have been a much cordial relationship between the two nations. Among all of those, historical and ongoing, the impact of some of those incidences are detrimental and unforgettable, including bombing of the Chinese embassy in former Yugoslavia, the using of unilateral and mercantilist approaches in the US China trade war, the ongoing ignorance of Chinese concerns over its sphere of sovereignty in Taiwan and the South China Sea, and the US's applying blunt yet very dangerous military approach on high seas deterring Chinese activities through flexing of muscles. The correlation of such complicated relationship therefore manages to generate a sense of ambivalence in the minds of Chinese people - the one that mixes admiration with interrogation.

\subsection{Americans: Why Against Liberal Expectation?}

On the American side, the relation with China has gone from cooperation, competition to most recent trending towards hostile competition. A short period around 10 years of cooperation between the two throughout 80's vanished rather quickly after two big events, the disappearing of Soviet Union, and the Tiananmen Square incident. To Americans, the role play of China in the game of great power relations is no longer a partner of geopolitics. It is rather the next political regime to compel for change in the same trajectory as found in Russia and Eastern European countries. With mixed results in the change of China, after so many bumpy incidents occurring between Clinton and Bush administrations, China was eventually granted a let go ticket to WTO. By 2010, China exceeded Japan in GDP, and has become world's number one manufacturing power house since. With China's catching up momentum, and overall economic power in substantial number of areas, American, for the first time in the last 100 years, seriously concerns about a looming much larger competitor. Together with China's "assertive" actions in the South China Sea, Obama initiates "Pivot to Asian" strategy. It is after Donald Trump, China has been constantly identified as "rivalry" and much lately as the number one challenger to its national core interest in all aspects. Among small spectrum of perspectives in the US think tanks, scholars, and governmental policy makers, views from moderate to radical, China is seen as revisionist, rules violator, a biggest challenger ever to the Caucasian civilization in the US history, and a Communist threat that needs to be contained (Ward, 2019; Lind, 2017).

\subsection{Anything Missing in Their Perceptions?}

In brief, China views the US carries on strategy of containing China for its rapidly rising economic and technological power, and blaming China for American's own problems; the US perceives China incompatible with the US values and system in all aspects, its intention to displace the US's hegemony, conducting unfair trade, China's political and military assertiveness, and reckless manor when comes to talk and treat the US.

These, however, have raised questions about the way each looks at the other. Are they really what you think who they are? Is there anything missing? History has taught people repeatedly that misperceptions are mostly the result of self-centric produce and is typified by mentally distorted, psychologically paranoid, methodologically denials-oriented cognitions. Such flawed approach at the state level could result in confusion and catastrophic consequences in their relations.

\section{Neglected Cognitive Similarities between the US and China}

Due to the syndromes of cognitive trap, learning process could be consciously or unconsciously selective. This basically means an actual object in person, event or venue could be distorted by ignorance or exaggeration. We believe, in a mostly troubled and mutually suspicious relationship between the US and China today, an effort to explore the neglected cognitive similarities may help for a sober and objective understanding. 


\subsection{They are Equally Reform Minded People}

First, reformist mentality is profoundly ingrained in the minds of the leaders and people in both countries, and serves a cognitive locomotive in their respective social transformation. Three development along this thinking and social practices in their socioeconomic changes can be found as useful examples.

\subsubsection{Revolutionary Legacy}

Number one, the founding fathers in both nations believed revolution is the only way to totally separate themselves from a decaying legacy and realize people's aspiration for a brand new society. The great American Revolution cast off a political autocracy in British rule. It was followed by the 1789 Constitution that created new federalist democracy for American people on the new land. Similarly, the overthrowing of the last empire of Qing Dynasty was seen by revolutionaries as an action to rescue China from national extinction. The revolutionary Mao with the support of the majority Chinese people had finally unified the mainland China and put the chaotic civil wars to an end. It is the strong revolutionary mentalities that motivated and mobilized the journey towards new regimes in both nations.

\subsubsection{Consistent Endeavors for Its Own Ideal Typed Society}

Number two, reform minded people in both nations have demonstrated their great courage to pursue ideal society through consistent endeavor in reforming flawed systems. Much credit should be granted to generations after new Constitution and their effort in their attempt to fix problems and loop wholes in American systems of party, factions, electoral procedures, campaign financing, human, civil and minority rights, and the role of government. Chinese leaders stumbled in their first thirty years by copying exotic model from the Soviet Union. However, the next forty years have witnessed the reflective ponderings, and most importantly their tenacious strife in rebuilding outlooks of the world, nation's infrastructure, socioeconomic systems, and more. The results of regime reforming mind set turn out that America has become the world's strongest and most developed country; China a swiftly rising economic power.

\subsubsection{Valued Social Innovation and Experimentation}

Number three, reform minded people in both nations have valued the spirit of innovation, and have been experimenting controversial yet path breaking strategies for social improvement. American doesn't trust judgment by individuals, and believes that governmental power ought to be separated. Over the last more than two hundred years, American managed to create a unique political system known as checks and balances. Despite criticism from different perspectives, this system guarantees that extensive political representation would be maximized, and the odds of abusing of power by dominant party and individuals to be minimized. This system turns out a much legitimate and stabilized choice for a multiethnic society in America. China on the other hand, the state has promoted boldest experimentations throughout the arduous course of reform since the 1980's. Some outstanding cases during the grand social experiments include Special Economic Zones (SEZs); dual price system, One Nation Two Systems (Hong Kong), mixed mechanisms in all aspects of economic transactions, and effective governance associated with bureaucratic meritocracy, and more. All of these has helped convert China from a below average poor into a world's leading economic power within just one generation time.

\subsection{Social Priority in Educational Excellence}

Secondly, the neglected cognitive similarity shared by the US and China is also represented by their tradition and great institutions for educational excellence. Education has always been solid value for family commitment, individual endeavor, and social mobility in both nations. America is today's world's capital for attending the best colleges and engaging first class scientific research. Every year, millions of youth talents flocked into educational institutions in the US. Among them, a substantial number of graduates with advanced degrees from some top ranked universities of the world have successfully become American scholars and researchers by virtue of the US immigration policy. They are both the pioneers and creators for the great miracle of Pax Americana. The United States of America has become a synonym of one of the most admired realms for science, engineer, technological inventions as well as human habitation. Similar value finds its counterpart in Chinese history and contemporary practices as well. In Max Weber's writing, the primitive source of modern bureaucracy can be traced back to Chinese tradition of examination system leading towards its monarchic bureaucracy. It is Chinese version of bureaucratic organization that constitutes the agents most approximate to the modern standards of equity, the bureaucratic efficiency and rationality (Weber, 1922c, 1955). In China, the value of seeking social advancement through best education incorporating with employment markets that embrace talents in STEM majors, have naturally catered economic take off and a continuing journey for nation's prosperity. The well educated citizens from college will be reaching 8.34 million by the end of 2019 (Xinhua quotes China Daily, 2018). The mounting number of youth talents would help reinforce the foundation of the grand scientific innovation and economic sustainability.

\subsection{Visions for Their Versions of Global Society}

Thirdly, unlike any other hegemonic empires, both countries are or becoming to be leaders with progressive visions for 


\section{Ignored Cognitive Differences between the US and China}

On the other hand, many seem to be much better aware of substantial differences between the two countries. However, because of cognitive habit, profound and unique historical and cultural sources behind such fundamental distinctions seem to be ignored when it comes to address the issue.

\subsection{The Big Society Small State Building in America}

The political and historical processes of state building in the US has been popularly acknowledged as the paradigmatic model for how state apparatus should be created, consolidated, stabilized and sustained. Framers of American state hated feudalistic social hierarchy and were enraged by the ubiquitous state's deprivation of their personal pursuit. With freedom rights of citizens and society as prime goal, the scope of individual happiness and liberty are maximized, and any state legal restrictions were deemed to be only supportive and auxiliary conditions to the personal and societal success. A s a result, the American political machines are expected to function just big enough to provide assistance for its citizens' personal pursuit, and small enough for the average people to survive with ample material supplies and personal liberty.

\section{2 "Nation-Family" and Congenial Partners of State-Society in China}

Some contemporary studies define Chinese political evolution by "civilization state" (Jacques, 2012), which is characterized by an incredible degree of longevity and diversification in the nation building. Primarily, Chinese fashion of nation-state building, despite of endless process full of cycle of unity and fragmentation after fundamental wars or changes, remains rock solid integrated since the era of Roman Empire. A second nature of Chinese state, as according to Marin Jacques' study, is featured by its intra-specific compatibility. It may only take a bit more thinking to understand the fact a diversified China could last for thousand years and stands still implicates what profound level of assimilation and tolerability a Chinese nation has so that it enables nurturing such amazing centripetal force that absorbs diverse cultures. China is now and as always a country many systems in reality. In fact, when Americans talk about pluralism and Chinese say a hundred flowers in bloom, they refer to a similar concept of multi-variation, and their tolerance and appreciation of diversity over uniformity.

A third layer of Chinese civilization state theory is the state and society relationship. The world wide polls on government popularity and level of legitimacy repeatedly demonstrate the higher government approval rating of Chinese government since the beginning of new millennium (Chen, W. 2017). This fact goes against western theories of liberal expansion after years of successful market development. State in the eyes of Chinese people, instead of being an object of suspicion and hostility, is mostly the hope and sources for protection, wealth and welfare. That way, state is the head and an important part of bigger family, which is literally termed as "nation-family" in Mandarin Chinese language. In today's extremely competitive international system of politics and economics, Chinese state has proved to be an ultimate source of Chinese miracles for an unprecedented socioeconomic mobilization and transformation.

\subsection{State's Role in the World: Exceptional or Harmony?}

As to world views, much more distinctive values and approaches of both countries also explain their grave disagreement on state's roles in international relations.. Americans consider themselves being exceptional, and the rest of the world needs to be rescued from wars and conflicts by a PAX Americana agenda. This believe implies the successful contributions the unique American people made with regard to American visions and institutional designing in the making of UN, international financial and trade regimes and so forth.

On the other side of the coin, the Chinese world views remains much internally conservative, balanced and harmonious oriented overall during much of its thousand years of existence as a Middle Kingdom. Several historical events unequivocally demonstrated these natures of Chinese state including Great Wall, the General Zhen He's seven times peaceful voyages to the west solely to delivered presents and good will to the nations along the trip from the Chinese Empire; and the China's modern history were mostly bothered by western colonial invasion, encroachment and resulting civil wars. One careful review and a fair judgment about Chinese government policies in the global affairs today shows that China's ultimate and supreme objectives are predominantly businesses (Walker, 2019) with intension to create good and sustainable fortunes for its own people, and reciprocal ties with vast majority of its global neighbors, nearby or in the far distances.

\section{Perceiving When Neglect Meets Ignorance}

However, the brutal reality is the prior addressed cognitive similarities and differences have been mostly either neglected or ignored, and managed to catch much lower attention than usually misinterpreted cognitive differences between the two nations.

Two years into Trump's administration, the American society seems to have reached a consensus that the US China 
relation has hit roadblocks due to incompatible differences over their core interests. Some blame China's operations include encroachment to the US state governments, universities, Chinese American communities, media, commercial and business circles for multi-purpose activities (Hoover Institution, 2018). Others criticize China for its assertive policies in South China Sea, Belt and Road Initiative, government trade protection, technology transfer and intellectual property theft (Summers, 2019). Still others call for a campaign to destruct Chinese Communist Party, to root out sympathy of China at home, and to combat China with strategic containment as the one against Soviet Union (Rogin, 2019). And which, is even prescribed by White House top policy advisor as clash between a White Civilization against non White Asian culture (Skinner, 2019). This study picks three debating issues for analysis in the attempt to explore the facts and misperceived cognitions leading towards such exacerbating relations.

\subsection{BRI - A Geopolitical Fight or Just Businesses?}

First, Belt and Road Initiative (BRI; Chinadaily2019) has been an ongoing subject that perplexes mutual trust and intensive economic cooperation between the US and China. Some of the major concerns interrogated by the US include alleged "debt trap" through BRI to the participating countries; the lack of "transparency" in the bidding process; and the geopolitical intention that puts nations' sovereignty in danger.

\subsection{1 "Debt Trap" vs. Reciprocal Investment}

The US is among very few that oppose the BRI initiative for several alleged reasons. BRI investment has pushed countries along the routes into dangerous "debt trap" is one of them. However, it is found that the accusation of "debt trap" by the US top officials on BRI is believed groundless as it is not supported by the real stats. Take Maldives' claimed "debt trap" issue and the truth told by actual numbers as an example. In his general statement, the president of the Maldives reported that his country has great debt crisis. According to CIA, the Maldives' national debt in 2017 is $68.1 \%$ of its GDP. By CIA's definition, a national debt is the funds raised by government in the format of bond for domestic operations, such as administrative expenses, medical expenses, educational expenses and other expenditures. Cross checking the definition and this debt level, Maldives claimed "debt trap" has nothing to do with debts owed to foreign investment parties. Its foreign debt by the end of 2016 stood at 848.8 million. IMF and World Bank's define foreign debt as strictly the liability of residents of foreign country for contractual repayment to non residents. Maldives didn't manage to provide the proportion of Chinese part of foreign debt, no stats on the contribution made by Chinese debt to its national GDP growth and employment (Feng \& Liang, 2018). So just to make an accusation by mixing two totally unrelated numbers is not only irresponsible, it is confusing and misleading. A few more recent studies done by American scholar show that blunt charge made by top US state officials on the so called China's "debt crisis" within 40 researched cases, particular the Port Hambantota in Sri Lanka, is widely misunderstood, overstated and mischaracterized (Chen, W. 2019). It was a 'snappy phrase' originally created by an Indian polemicist that is being accepted by many. Opposite to a 'debt trap', it is actually a 'stranded asset' for which Chinese company has to put extra investment to build the economic hinterland for the port (Freeman, 2019).

This rebuttal could also serve a reminder of history of debt issue in many developing countries. The 1970's OPEC actions did contribute to the soaring debts in all countries, particularly those pursuing import substitution developmental strategy. It is actually a BRI's policy that a "non-mandatory" policy based on IMF and World Bank's standard to assess debt risk before making lending decisions. The goal is to balance long term and sustainable BRI investment and debt risk (Chen, J., 2019).

\subsubsection{Debate over Transparency for Investment Opportunity}

By the same token, BRI is criticized for not being "transparent" when comes to decision making for investment opportunity. However, many private owned enterprises have also found equal footing in winning contract opportunities with their real competitive capacities. Since day one of the BRI initiative, GE has been successfully beating out many private and public competitors from China, earning itself $\$ 2.3$ billion of contract orders, and is now pushing for an additional $\$ 7$ billion in orders for natural-gas turbines and heavy power equipment. In the same vein, Citibank - one of world's largest financing power houses, won a contract bidding from the Bank of China in 2016. This allows the company to manage bonds estimated at $\$ 3$ billion to raise money for its extensions all over Asia, Eastern Europe and East Africa. Another US technology and manufacturing company Honeywell has been allowed to sell its equipment to Central Asia for processing natural gas (Bradsher, 2017). Other foreign firms are expecting positive collaboration with BRI projects with their unique potentials and instant impact (Shepard, 2017; Cendrowski, 2016; Coresight, 2016).

It has found projects along the BRI routes, multiple zones of competition are existing among ADB (Asian Development Bank), MDB (multilateral development bank), and Eastern Central European funders, in addition to AIIB (Asian Infrastructure Investment Bank). Table 2 indicates many existing projects funded by multilateral development banks for the contractors participating in projects. Of them, 29 percent are Chinese, 40.8 percent are local, and 30.2 percent are foreign (Hillman, 2018). Having such a record is a strong testimony for the improving of transparency levels in the 
overall initiative, especially when considering the extreme competitiveness of Chinese transportation sectors. Both western and local firms will continue to find success in BRI investment with their advantages in technologies, as well as their consultation and legal services.

Table 2. Percentage of Multiple Zones of Funders in the BRI Projects

\begin{tabular}{|l|l|l|l|}
\hline Zones & China & Local & Foreign \\
\hline Percentage $\%$ & $29 \%$ & $40.8 \%$ & $30.2 \%$ \\
\hline
\end{tabular}

Source: Hillman, J. (2018). China's Belt and Road Initiative: Five Years Later, CSIS (Center for Strategic and International Studies) Report.

\subsubsection{A Geopolitical Conspiracy over Sovereignty?}

The geopolitical intention is another criticism about BRI. The economic corridor between China and Pakistan is one of the most discussed issues in this regard. The core of the problem lies in this geographic connection that runs across the disputed area of Kashmir for which both India and Pakistan claim its sovereignty. China has offered India to rename the connectivity from CPEC (China Pakistan Economic Corridor) to an alternative name based on another possible route, if India joins BRI (Dasgupta, 2017). After rounds of confrontation on land and the ocean in the past year, the most recent development between these two Asian giants has witnessed their willingness to keep dance together between the Dragon and the Elephant. When history and colonialism created the boarder problems between the two, rational leaders and cultural ties will eventually get along as no one can remain isolated for too long in the name of sovereignty (Mohan, 2017). Among all possible solutions, only peace and good neighbor seem a most realistic and plausible choice for the parties on both sides.

\subsection{Models of Development: Normatively Exclusive or Functionally Competitive?}

Secondly, to many Americans, the Chinese model of development is not only beyond normative understanding, it is wrong. This cognitive judgment believes the thinking and performance of China's model are heterodoxy that goes against the western value of democracy and market economy. Worst of all, Beijing has stubbornly addicted to authoritarianism and state directive market economy (Freeman, 2018).

On the other hand, China's consistent grow at average 9\% even since 2008 international crisis, and its much appreciated role model effect on developing nations' economic strategy put western value based systems in a rather embarrassed position (Ross, 2011). With the debate going on between so called Washington Consensus (WAC) and Beijing Consensus (BJC), many questions need to be addressed.

\subsubsection{The Changes in China}

In just about less than 40 years (policies leading to the rapid growth in majority first tier cities of China's were not granted by the central government until after the middle of 1990), China has accomplished earth shaking transformation in its socioeconomic development. The poverty alleviation for 800 million people; the amazing rise of its economy from very bottom to world's number two by GDP, and number one by PPP (purchasing power parity); the anticipated number of middle class people - moderate prosperous population - by UN standard will reach 600 million by 2022 , which accounts for $76 \%$ of urban families, and $45 \%$ of total population (Daxue, 2016); the world wide outbound tourism has reached 149.72 million trips, and domestic at 5,539 million trips by 2018 (Travel China Guide, 2019). The general population's approval rate, or the sense of trust and satisfaction with the Chinese government has remained around 85-90\% over the years since 2008 (Edelman, 2018). Moreover, the overall global approval rate on the major powers in world affairs and their relationship with partners in Latin America, Asia and Africa has put China on top over USA, Russia, Germany and others (Gallup Report, 2019).

\subsubsection{The Washington Consensus}

In contrast to the development in China, Latin American states are the most loyal followers of Washington Consensus. However, the adoption of the principles promoted by western states, IMF and World Bank turned out to be detrimental for some of these students at global south. Argentina, for example, one of fundamental believers of WAC, strictly conformed the given prescriptions, after short surging in 1990, started losing much of its momentum, and ended up completely collapsed by 2001 (Oniz, 2004). Similar experience was observed as happening to many Latin American states where seven years of strong growth followed by seven years of stagnation and recession (Narcis \& Stiglitz, 2008). The mixed results have been witnessed in the political and economic changes in Russia and Central Asia, Eastern Europe, north Africa and Middle East nations, where economic performances turn out mediocre among most of them, 
the radical push for regime change has resulted in political chaos, civil wars, terrorist movement, poverty and massive efflux of refugees among others.

\subsubsection{Understanding Chinese Model of Economic Development}

China's transformation provides one of the most compelling precedence by virtue of its overall success. The metaphor from functionalist perspective indicates wherever policies are compatible with existing local conditions, and conducive to public's needs, being orthodoxy or heterodoxy, they are going to survive and shine.

The biased cognition in the west about change in China is causing their misperceptions. So, what have been missing is basic yet fundamental. Economically, China embraces concept and policies of free market. Chinese government announced that private enterprises were responsible for over 60\% of China GDP by the yare of 2014. In east coast areas, the private enterprises accounted for $80.81 \%$ of all revenues in recent times. By the year of 2019 counts, private businesses have contributed to $60 \%$ of China's GDP, and are responsible for $70 \%$ of innovation, $80 \%$ of urban employment and provide $90 \%$ of new jobs. Private wealth is also responsible for $70 \%$ of investment and $90 \%$ of exports (People Net, 2014; Guluzade, 2019). However, like successful economies everywhere including Western European states, China reserves state businesses and the role of the state in managing businesses (Wade, 2003). The state investment in infrastructure and associated industries inject formidable dynamism to push and pull economic growth. The critics over China's experience may need to understand that as a rational player in the free market, countries are always dictated by real rationality of human being. Reviewing how Great Britain and the US used to act like huge fans of mercantilism during their rising eras would clear up puzzles lot people may have with China's policy today. And is it still a moral commitment of developed countries to their former colonies by granting favorable yet tentative leniency as way to share pretty concentrated wealth with their not so fortunate brothers? We believe this should remain a serious question for pondering.

\subsubsection{Understanding Chinese Model of Political Transition}

Debate along perceptions between the US and China may get much intense with regard to the political and social changes in China. It is our argument that slowly yet steadily improving flawed institutions and social order are indispensable to any successful socioeconomic transformation. The beauty of China's rise lies exactly in the co-evolution of tradition and reality. That takes patience and is time consuming. It differs from institutional approach that stresses on constitutional and political framework as preconditions for a democratic system (Dahl, 1988; Tocqueville, 2000). It also disagrees with Huntington's teaching that changing societies would have to be inflicted by vicious circle between rising participation and the rule of military strongmen (Huntington, 1968).

Studies have shown that at least three essentials have featured political and social transformation in contemporary China today. Number one, the national consensus for never ending reform and innovation is the real myth for the China's success (Ramo, 2004; Leonard, 2006). This approach advocates change with an incremental approach. It all started from de-ideological movement and is trending towards conviction of utilitarian motto: "seek truth from facts". And it drives constant tinkering and evolution in all aspects of life with the recognition that different strategies are needed to cope with complex situations. Number two, Chinese political leaders legitimized by processes of meritocracy plus election are among the best who have the wisdom and sophistication to provide wealth, sense of confidence and the trust to the people at home and abroad (Sun, 2014), as this Harvard conducted poll demonstrated. The political implication of this poll indicates that the real regime legitimacy is rooted in actions rather than normative processes or beautiful rhetoric. Number three, politics of deliberation bridges the governance and popular feedbacks that contributes to an overall harmonious social order. Over the years, some efficient communication protocols between the rulers and the ruled have been explored and experimented so that government performance has been placed under closer watch by general public, and the potential social chaos could be well managed (Qian \& Huo, 2017; Ogden, 2002).

\section{Is Containment Policy an Answer to the Differences?}

Thirdly, a corollary from above misperceptions over the changes in China seems to have precipitated American elites to raise a sensational yet dangerous proposal of containment. For them, due to a geopolitically assertive China in the South China Sea and through belt and road, its anti-democratic value in their political and economic systems, and its rising economic and technological power threatening the US national and cyber security, the US needs a China containment policy (Rogin, 2019; Shanahan, 2019; Freeman, 2019).

The challenge to the US policy makers is how they figure out the equation between last Cold War containment and today's proposed one against China? Do they really understand China and its behavior? And more. All prior living evidences have proved that it could be a huge tragic mistake to judge today's China as yesterday's Soviet Union. The fact that we might have already been confused by reading the series of questions listed above may have appalled everyone in the audiences. However, it doesn't matter. All that matters is what those in the position to navigate the 
trajectory, and the measurements they utilized for calibration. The measurements for the decisions are what and how they visualize the world.

\section{It's All a Matter of Perception and Conclusion}

\subsection{Syndromes of Faulty Cognition Reviewed}

When neuroscientists analyze misperceptions, they believe thinking process could be overwhelmed by pervasive negativity (Burns \& Heuer, ibit). In the language of international politics, studies also show the policy results are simply a matter of how politicians perceive information (Jervis, 1988). Relations among great powers are most often handled with higher level of hostilities due to misperceptions. Therefore, the identical syndromes occurring in both medical science and politics, such as mirror image, inappropriate analogies, ethnocentric assumption, lack of empathy, and denial of rationality are the causes thrusting us into a cognitive trap. But does it also imply that in order to reach harmonious relations between great powers, would the antonyms of these syndromes be possible alternatives? Another words, the great power relations doesn't have to be Thucydides' hostile, it could be European Concert cooperative or today's cooperative relations across the Atlanta Ocean - blending of controversial agenda and an illusionary good will cooperation. After all, action is a matter of perception!

\subsection{Is Coercive Approach a Solution to the Differences?}

The problem is even if the perception is that the US and China is "destined" for war, is that even close to a realistic solution? In another words, can any other regular wars be served as an analogy to handle the relations through an imagined war between two nuclear superpowers? And all of this is just because someone believe that China will certainly intend to displace the US and to become world's number one; China could do what US did after 1895; China's "repressive" domestic policies; and its audacity or reckless and rude behavior towards the US especially after the 2008 international financial crisis (Allison, 2017; Johnston, 2013; Swaine, 2018).

It is obvious that some people inside the US and around the world, intentionally or unintentionally, become obsessed with disseminating sensational atmosphere that the US and China is destined for a real military face off, meaning a nuclear showdown (Ignatius, 2016; Lee, 2019), in addition to a total socioeconomic disengagement (Rogin, 2019). Others, however, speaking with a clear common sense that the US and China relations doesn't fit Cold War pattern (Freeman, 2018, 2019). Like it or not, the coercive nuclear option to subdue rivals for a game between two great powers only highlights an extremely desperate and suicidal dilemma. All things considered, there are actually not much ultimate options available on the table for a difficult relations between the two. A consensus that may be "uncomfortable" yet would contribute to create a zone of possibility for the reciprocity. And that is the US and China are destined only for co-evolution and cooperation, or "we both shall be blamed for" (Nye, 2019; Freeman, 2018).

\subsection{Self-conscious Sensitivity for Cognition}

This leaves the antonyms of negative cognitive syndromes as alternative. A rather contrasting method for nations' relations could be, first of all, taking considerate, altruistic, empathetic and generous approach. In such case, avoid self-centric mentality and being understandable and tolerant are the very essence that encapsulates quite a few honorable virtues for handling relationships (Avery, 2001; Maiborm, 2017). We believe this approach may well heal the cognitive defects associating with mirror image, inappropriate analogies, ethnocentric assumption and lack of empathy. On the other hand, tolerance cannot escape from differences. Benign communication may help ameliorate differences. However, the best way for people and countries to grow is allowing them to take spontaneous actions for change (Deci \& Ryan, 1985). So assuming rational is a second alternative to redress cognitive bias over denial of rationality. The most distinctive effect of this approach lies in respect of self-determination, and the trust of human nature to maximizing consenting goodness based on facts and reason.

Along these lines to recognize the cognitive habit and inclination, IR scholars call for self-conscious sensitivity to minimize chances of misperceptions in international relations. Martha Nussbaum and Sarah Ellen Graham argue emotions are an essential element of political reasoning of persuasion and argument (Nussbaum, 2013; Graham, 2014). Such self-centric and irrational thinking pattern could be as awfully misleading as policy decisions to invade Iraq and predatory lending in Global Financial Crisis (Widmaier \& Park, 2012). Robert Jervis' insights on strategies to minimize misperceptions shed the light for cognition management. These strategies start with ideas of tolerance by rendering rival parties a clear comprehension of your cognition and predictions; allowing opposite voices to challenge and adjust the mainstream policy options; continue with wisdom in rationality by separating personal identities and interests from brand new situations and events; and by avoiding overestimating rivalries' hostility yet underestimating their ability of counterbalancing (Jervis, 1976). All of these advices for a health cognition along self-conscious sensitivity could be funneled into a category of rationality with which human civilization relies and survives. 


\subsection{Human Rationality}

Despite a controversial topic, human rationality is commonly understood as human who separates himself from other creatures in his respect of facts that are agreeable with reasons. To Max Weber, the essential element divides a traditional society and modernity lies in science and rational calculation of social actions. This connotation of rationality is specified as an attribute based on mathematics and exact and rational experiment. This constitutes the core value of modern society as rationality. Therefore, the modern government institutions are constructed along critical substance of rationality, which in return shapes the plans, strategies, norms, rules, and standard operating procedures in the routine government operations (Weber, 2006).

In the relationship between superpowers, any frenzied thoughts to subjugate opponents with violence, whether economic, political or military, are not only antiquated but suicidal. Co-evolution and reciprocity are the commonly taken rational thoughts and easiest passage to peace and prosperity for everyone. The metaphorical meaning of assuming rational is a cognitive attitude to preventing arbitrary intervention and for acknowledging self-steered learning and correction. After all, the ends justify means is a cognition for diversity over uniformity. With rationality, the roads to the common destiny could still be tortuous, but human biases should eventually be given way to prudence and righteousness.

\section{References:}

Allen, C. (2014, July 28). Important Lessons Learned from World War I. USA Today.

Allison, G. (1999). Essence of Decision: Explaining the Cuban Missile Crises (2nd ed.). Pearson.

Allison, G. (2015, September 24). The Thucydides Trap: Are the US and China Headed for War? The Atlantic.

Allison, G. (2017). Destined for war: Can America and China escape Thucydides' Trap? Boston, Houghton Mifflin Harcourt.

American Foreign Relations. Containment - Critiques of $m r . \quad x^{\prime} s$ doctrine. Retrieved from https://www.americanforeignrelations.com/A-D/Containment-Critiques-of-mr-X-s-doctrine.html

Avery, P. G. (2001, December). Developing Political Tolerance, Eric Educational Reports.

Bradsher, K. (2017, May 17). U.S. Firms Want In on China's Global 'One Belt, One Road' Spending. The New York Times.

Bull, H. (1977). The Anarchic Society: A study of World Politics. London: The Macmillan Press Ltd., 24-27, 41, 51,-52. https://doi.org/10.1007/978-1-349-24028-9

Burns, D. B. (2008, Reprinted) Feeling Good: The New Mood Therapy. Happer.

Cendrowski, S. (2016, December 12). Inside China's Global Spending Spree, Fortune.

Chang, G. (2001). The Coming Collapse of China. Random House.

Chen, J. (2019, April 29). Leveraging private funds prioritized in BRI projects. China Daily.

Chen, W. H. (2017, Oct. 27). Chinese Trust Government more than Americans do. China Daily. Retrieved from http://www.chinadaily.com.cn/opinion/2017-10/27/content_33762163.htm

Chen, W. H. (2019, May 13). US Studies say BRI not a Debt Trap. China Daily.

Chinadaily. (2019, March 7). China trade with BRI countries, regions crosses US\$6 trillion. chinadaily.com.cn. Retrieved from http://www.china.org.cn/business/2019-03/07/content_74541427.htm

Coresight Research. (2016, October 3). Deep Dive: One Belt One Road - Impact On Western Multinational Companies. Retrieved from

https://coresight.com/research/deep-dive-one-belt-one-road-impact-western-multinational-companies/

Dahl, R. (1988). On Democracy. Yale University Press.

Dasgupta, S. (2017, November 23). China Hints it Can Rename CPEC if India Joins OBOR Initiative. The Times of India. Retrieved from

https://timesofindia.indiatimes.com/india/china-shows-interest-in-talking-one-belt-one-road-plan-with-india/article show/61771677.cms

Daxue. (2016, January). China's Middle Class and its consumption pattern, daxueconsulting. Retrieved from https://daxueconsulting.com/china-s-middle-class/

Deci, E. L., \& Ryan, R. M. (1985). Intrinsic Motivation and Self-Determination in Human Behavior. New York, NY: Plenum. https://doi.org/10.1007/978-1-4899-2271-7 
Deudney, D., \& Meiser, J. (2012). American Exceptionalism. US Foreign Policy, Oxford University Press (2nd Ed.). 21-37. https://doi.org/10.1093/hepl/9780199585816.003.0002

Edelman. News \& Awards. (2018, January 22) Edelman Trust Barometer. Retrieved from https://www.edelman.com/news-awards/2018-edelman-trust-barometer-reveals-record-breaking-drop-trust-in-the-u $\mathrm{s}$

Feng, D. H., \& Liang, H. M. (2018, November 21). "Is BRI road to a 'debt trap'? The numbers says no. Global Times. Retrieved from http://www.globaltimes.cn/content/1128434.shtml

Freeman, C. J. (2018, May 5). On the Souring of Sino-American Relations - Remarks to the Committee of 100. Santa Clara, CA. Retrieved from https://chasfreeman.net/on-the-souring-of-sino-american-relations/

Freeman, C. J. (2019, May 3). On Hostile Coexistence with China-Remarks to the Freeman Spogli Institute for International Studies China Program. Stanford CA. Retrieved from https://chasfreeman.net/on-hostile-coexistence-with-china/

Fukuyama, Francis. (1992). The End of History and the Last Man. Penguin UK, or Macmillan USA

Gallup Report. (2019). "America First?" Rating World Leaders: 2019. Retrieved from https://www.gallup.com/analytics/247040/rating-world-leaders-2019.aspx

Graham, S. E. (2014). Emotion and Public Diplomacy, Dispositions in International Communications, Dialogue and Persuasion. International Studies Review, 16(4), 522-539. https://doi.org/10.1111/misr.12156

Guluzade, A. (2019, May 7). Explained, the role of China's state-owned companies. World Economic Forum. Retrieved from https://www.weforum.org/agenda/2019/05/why-chinas-state-owned-companies-still-have-a-key-role-to-play/

Heuer, R. J. J. (2007). Psychology of Intelligence Analysis (2nd ed.). Pherson Associates LIc;

Hillman, J. (2018). China's Belt and Road Initiative: Five Years Later, CSIS (Center for Strategic and International Studies) Report.

Hoover Institution. (2018, November 29). China Influence and American Interests: Promoting Constructive Vigilance. $A$ Publication of Hoover Institution. Retrieved from http://theory.people.com.cn/n/2014/0825/c388253-25532859.html

Huntington, S. P. (1986). The Political Order in Changing Societies. Yale University Press.

Huntington, S. P. (1996). The Clash of Civilization and the Remaking of World Order. New York, NY: Simon and Schuster. Ignatius, D. (2016, March 25). The US is heading toward a dangerous showdown with China. The Washington Post.

Jacques, M. (2012) When China Rules the World: the End of the Western World and the Birth of a New Global Order. (2nd ed.). Penguin Books.

Jervis, R. (1976). Perception and Misperception inn International Politics. Princeton University Press. Chapter 12.

Jervis, R. (1978). Cooperation Under the Security Dilemma. World Politics, 2. https://doi.org/10.2307/2009958

Jervis, R. (1988). War and Misperception. The Journal of Interdisciplinary History, 18(4), 675-700. https://doi.org/10.2307/204820

Johnston, A. I. (2013, Spring). How New and Assertive Is China's New Assertiveness? International Security, 37(4), 7-48. https://doi.org/10.1162/ISEC_a_00115

Ketchell, M. (2017, May 17). The Belt and Road Initiative: China's vision for globalization, Beijing-style, The Conversation. Retrieved from http://theconversation.com/the-belt-and-road-initiative-chinas-vision-for-globalisation-beijing-style-77705

Lee, J. (2019, January 24). Did Thucydides Believe in Thucydides Trap? The History of the Peloponnesian War and Its Relevance to U.S.- China Relations. Journal of Chinese Political Science, 67-86. https://doi.org/10.1007/s11366-019-09607-0

Lenin, V. I. (1996). Imperialism: The Highest Stage of Capitalism. Pluto Press, May 20.

Leonard, A. (2006, September 16). "No Consensus on the Beijing Consensus", Salon. Retrieved from https://www.salon.com/2006/09/15/beijing_consensus/

Lind, J. (2017). Asia's Other Revisionist Power. Foreign Affairs.

Lippmann, W. (1973). The Cold War: A Study in US Foreign Policy since 1945. Reading, PA: Addison-Wesley. 47, 49-51.

Maiborm, H. L. (2017). The Routledge Handbook of Philosophy of Empathy. Routledge. 1-9. 
https://doi.org/10.4324/9781315282015-1

Marx, K. (1996). Das Capital: A Critique of Political Economy. Regnery Publishing, Inc., USA.

Mohan, G. (2017, October 6). Bangladesh backs China's OBOR; can't remain isolated in the name of sovereignty, says foreign secretary, India Today. Retrieved from

https://www.indiatoday.in/world/story/bangladesh-backs-obor-china-cpec-initiative-shahidul-haque-india-1058853 $-2017-10-06$

Narcis, S., \& Stiglitz, J. E. (2008). The Washington Consensus reconsidered: towards a new global governance. Oxford: Oxford University Press.

Nussbaum, M. C. (2013). Political Emotions: Why Love Matters for Justice. Cambridge, MA: Belknap Press.

Nye, J. (2019). 'Mei Zhong he zuo, ming zhong zhu ding' 'The US and China are Destined for Cooperation'. Interview Joseph Nye by Mr. Zhou. L. J. C. China US Focus. Retrieved from https://mp.weixin.qq.com/s?_biz=MzA4NDMwNDM3Mg==\&mid=2650244081\&idx=1\&sn=13274f57ac3066be 068892223f99c83d\&chksm=87ea6b6ab09de27cc6b234b89d502860c8d32eb6c964752c253fa9932da3bd680c1fc20 d9c33\&mpshare $=1 \&$ scene $=1 \&$ srcid=0417IeulfHr2LyL7LIdcyzPT\#rd

Ogden, S. (2002). Inklings of Democracy in China. New York: Harvard University Asian Center, 100-101. https://doi.org/10.2307/j.ctt1tg5ms0

Oniz, Z. (2004). Argentina Crisis, the IMF, and the limits of neo-liberal globalization: a comparative perspective. Review of International Affairs. https://doi.org/10.1080/1475355042000250511

People Net, (2014, August 25). Modernization of State Governance, State Ownership vs. Private Enterprises - Walking with Two Legs. Retrieved from http://theory.people.com.cn/n/2014/0825/c388253-25532859.html

Pew Research Center. (2017, Spring). Depending on the country, US or China is the more favored nation., Global Attitudes Survey, Q12a.c,e. Retrieved from

https://www.pewresearch.org/fact-tank/2017/08/23/in-global-popularity-contest-u-s-and-china-not-russia-vie-for-fi rst/ft_17-08-11_china_us_russia_table/

Qian, Z. J., \& Huo, S. T. (2017, April 14). Politics of Participation - In Search for Deliberative Governance in China. Open Journal of Political Science, 257-266. https://doi.org/10.4236/ojps.2017.72020

Ramo, J. C. (2004). The Beijing Consensus. The Foreign Policy Centre. 12.

Rapoza, K. (2011, July 31). What So Great About China? Forbes.

Rogin, J. (2019, April, 10). China Hawks call on American to fight a new Gold War. The Washington Post.

Ross, J. (2011, December 15). Fairy stories about China's 'economic crisis'. Key Trends in Globalization. Retrieved from https://ablog.typepad.com/keytrendsinglobalisation/2011/12/fairy-stories-about-chinas-economic-crisis.html

Shanahan, P. M. (2019, June 1) Acting Secretary of Defense, signed, "Indo-Pacific Strategy Report: Preparedness, Partnership, and Promoting a Network Region". The US Department of Defense.

Sheng, H. S. (2016, January). Municipal Law Basis for China's Participation in UN Peacekeeping Operation, Law Review. Retrieved from http://en.cnki.com.cn/Article_en/CJFDTotal-FXPL201801013.htm

Shepard, W. (2017, March 12). These 8 Companies Are Bringing The 'New Silk Road' to Life. Forbes.

Skinner, K. (2019, April). On Clash of Civilization between the US and China. Washington Examiner.

Summers, L. (2019, March, 29). Four Observations on the US China Relations. Financial Times.

Sun, W. M. (2014, December 18). Xi Jinping Receives Highest Rating among World Leaders: Harvard Survey, Crienglish.com News. Retrieved from http://english.cri.cn/12394/2014/12/18/3123s857204.htm

Swaine, M. D. (2018). A Relationship Under Duress: U.S. China Relations at a Crossroads, China program of the Carter Center and the Institute of American Studies. Chinese Academy of Social Science.

Tocqueville, A. (2000). Democracy in America. Bantam Classics. https://doi.org/10.7208/chicago/9780226924564.001.0001

Travel China Guide. (2019, April 22). 2018 China Travel Tourism Facts \& Figures, Travel China Guide. Retrieved from https://www.travelchinaguide.com/tourism/2018statistics/

Wade, R. (2003). Governing the market: economic theory and the role of government in East Asian industrialization. New York, Princeton University Press. 297. 
Walker, P. (2019). Powerful, Different, Equal, Overcoming the Misconceptions and Differences between China and the US. LID Publishing.

Wang, M. Z. (2016, June 6). China to Become Second Largest Contributor to UN Peacekeeping Budget. The Telegraph. Retrieved from https://www.telegraph.co.uk/sponsored/china-watch/politics/12210677/china-contributions-un-peacekeeping-budg et.html

Wang, W. Z. Y. (2019). Destined for Misperception? Status Dilemma and the Early Origin of US-China Antagonism, Journal of Chinese Political Science, January 10. https://doi.org/10.1007/s11366-018-09596-6

Ward, S. (2019, May 4). Because China isn't 'Caucasian,' the U.S. is Planning for a 'clash of civilizations.' That could be dangerous. Washington Post.

Weber, M. (1922c, 1955). The Religion of China: Confucianism and Taoism. Glencoe, III: Free Press. Chapter 2-4.

Weber, M. (2006). Rationality and Modernity. Routledge.

Widmaier, W. W., \& Park, S. (2012). Differences Beyond Theory: Structural, Strategic, and Sentimental Approaches to Normative Change. International Studies Perspectives, 13(2), 124. https://doi.org/10.1111/j.1528-3585.2012.00459.x

Wilson, W. (1999). The Fourteen Points: Wilson's Address to Congress, January 8, 1918. From Williams, G. \& Shafritz, Classic Readings of International Relations, Wadsworth: a division of Thomas Learning.

Worstall, T. (2016, October 30). China's Only 15\% of the Global Economy But Contributes 25-30\% of Global Economy. Forbes.

Xinhua. (2018, November). China to see 8.34 Million college graduates in 2019. China Daily.

Yan, W., \& Freeman, C. W. (2018). Discussion on China, and Urges the US to Maintain Healthy Relations with China. Global Times, December 31. Retrieved from http://globaltimes.cn/content/1134134.shtml

Zhao, Y. K. (2014, October, 2). What Drives China's Success? Forbes.

\section{Copyrights}

Copyright for this article is retained by the author(s), with first publication rights granted to the journal.

This is an open-access article distributed under the terms and conditions of the Creative Commons Attribution license which permits unrestricted use, distribution, and reproduction in any medium, provided the original work is properly cited. 